\title{
AUTOLOGOUS PLATELET-RICH PLASMA: A REVIEW OF SCIENTIFIC ARTICLES ON THE STUDY OF EFFICIENCY IN TREATMENT OF ANDROGENETIC ALOPECIA IN MEN AND WOMEN
}

\author{
Julia Ovcharenko, Olena Salenkova \\ V. N. Karazin Kharkiv National University, 6 Svobody Sq., Kharkiv, 61022, Ukraine, \\ e-mail: med@karazin.ua
}

This article is an analysis of scientific publications that reflect the experience of using autologous plateletrich plasma in patients with androgenic alopecia (AGA), a multifactorial genetically predisposed disease caused by the influence of exogenous or endogenous triggers responsible for the clinical manifestations of pathology. Attention to this topic is due to the significant prevalence of AGA, as well as unsatisfactory results in achieving a positive therapeutic effect.

KEY WORDS: androgenic alopecia, autologous platelet-rich plasma, trichology, immunology

\section{АУТОЛОГІЧНА ЗБАГАЧЕНА ТРОМБОЦИТАМИ ПЛАЗМА: ОГЛЯД НАУКОВИХ СТАТЕЙ ЩОДО ВИВЧЕННЯ ЭФЕКТИВНОСТІ В ЛІКУВАННІ АНДРОГЕНЕТИЧНОЇ АЛОПЕЦІЇ У ЧОЛОВІКІВ ТА ЖІНОК}

Овчаренко Ю. С., Саленкова О. А.

Харківський національний університет імені В. Н. Каразіна, пл. Свободи, 6, м. Харків, 61022,

Україна

Дана стаття являє собою аналіз наукових публікацій, що відображають досвід застосування аутологічної збагаченої тромбоцитами плазми у пацієнтів 3 андрогенною алопецією (АГА) мультифакторіальним захворюванням с генетичною схильністю, зумовлене впливом екзогенних або ендогенних тригерів, відповідальних за клінічні прояви патології. Увага до цієї теми зумовлена значною поширеністю АГА, а також незадовільними результатами у досягненні позитивного терапевтичного ефекту.

КЛЮЧОВІ СЛОВА: андрогенна алопеція, аутологічна збагачена тромбоцитами плазма, трихологія, імунологія

\section{АУТОЛОГИЧНАЯ ОБОГАЩЕННАЯ ТРОМБОЦИТАМИ ПЛАЗМА: ОБЗОР НАУЧНЫХ СТАТЕЙ ОБ ИЗУЧЕНИИ ЭФФЕКТИВНОСТИ В ЛЕЧЕНИИ АНДРОГЕНЕТИЧЕСКОЙ АЛОПЕЦИИ У МУЖЧИН И ЖЕНЩИН}

Овчаренко Ю. С., Саленкова Е. А.

Харьковский национальный университет имени В. Н. Каразина, пл. Свободы, 6, г. Харьков, 61022, Украина

Данная статья представляет собой анализ научных публикаций, которые отражают опыт применения аутологичной обогащенной тромбоцитами плазмы у пациентов с андрогенная алопецией (АГА) - мультифакториальном заболевании с генетической предрасположенностью, обусловленное влиянием экзогенных или эндогенных триггеров, ответственных за клинические проявления патологии. Внимание к этой теме обусловлено значительной распространенностью АГА, а также неудовлетворительными результатами в достижении положительного терапевтического эффекта.

КЛЮЧЕВЫЕ СЛОВА: андрогенная алопеция, аутологичная обогащенная тромбоцитами плазма, трихология, иммунология

\section{INTRODUCTION}

(C) Ovcharenko Yu. S., Salenkova O. A., 2018
Currently, most researchers consider androgenic alopecia (AGA) as organ-specific 
segmental accelerated aging of hair follicles that occurs in individuals with a genetic predisposition due to the influence of exogenous or endogenous triggers that are responsible for the clinical manifestations of the disease with the leading role of endocrine disorders [1]. Significant progress has been made in understanding the basic elements of the metabolism of the participating androgens with a clearly expressed genetic component. However, clinical practice has shown that simply blocking androgens does not give the desired results [2]. Clinical and research progress helped to identify several nonandrogenic cofactors of complex etiology of AGA, which became a prerequisite for the development of new therapeutic strategies, among which the use of autologous platelet-rich plasma (PRP) is one of the most promising. The published data of fundamental and clinical studies on the effectiveness of the use of PRP in the treatment of AGA will be analyzed in this article.

\section{EFFECTS OF GROWTH FACTORS ON THE HAIR FOLLICLE}

Hair follicles are located at the intersection of complex neuroendocrine and immune regulation, actualizing both local and systemic influence of numerous endogenous and exogenous factors, genome and epigenome. The information we know probably comprises a small amount of what future discoveries will bring. Increased awareness of the various signaling pathways involved in hair growth may further lead to the discovery of new targets for drug exposure.

Thus, it was demonstrated in researches Botchkarev et al. (Botchkarev V. A. et al, 2003) [3] that the transition from the telogen to anagen phase is associated with the activation of the Shh, Wnt/beta-catenin/ Lef-1 and Stat3 signaling pathways. A huge number of signal transduction pathways (Shh, Wnt, etc.) and growth factors (BMP, FGF, HGF, IGF, PDGF, SCF, etc.) are activated in the anagen phase in the epithelium and mesenchyme, which should be well coordinated for hair formation.

It should be noted that the same factors can have a completely opposite effect on the cells in the follicle in different phases of the cycle. Modern research has opened up an enormous potential for developing of methods of correcting and managing the hair growth cycle with the help of biologically active substances, growth factors and hormones and in fact revolutionized this direction.

Growth factors - polypeptides with a molecular weight of 5-50 kDa, combined into a group of trophic regulatory substances. Like hormones, these factors have a wide range of biological effects on many cells - they stimulate or inhibit mitogenesis, chemotaxis, differentiation. Unlike hormones, growth factors are produced by unspecialized cells located in all tissues as a rule, and possess endocrine, paracrine and autocrine action.

Growth factors - a link between the expression of the body genes and the environment - play an important role in regulating the life of the hair follicle. Currently, it has been established that such factors as EGF, TGF- $\beta$, IGF-1, HGF, KGF, VEGF are involved in the regulation of the hair growth cycle [4].

The localization of receptors for a number of growth factors in various parts of the hair follicle was demonstrated by immunohistochemistry and in situ hybridization. The dermal papilla cells demonstrated the highest immunogenic reactivity against FGF-7, IGF, HGF and VEGF, which play a key role in the regulation of follicle growth. Initially it was expected that the use of growth factors in vivo will allow having a stimulating effect on hair growth. Nevertheless, an interesting feature was revealed during the research: the effect of growth factors on the hair follicle depends on the nature of the implementation of their action.

It was found that growth factors such as EGF, TGF-a, FGF-1. FGF-2, slowed hair growth. A suppressive effect was also observed in TGF- $\beta$ in tissue culture. This group of growth factors was characterized by an autocrine mechanism of action.

At the same time, it was demonstrated that subcutaneous injections of FGF-7, IGF-1, HGF paracrine growth factors stimulated the growth of the hair follicle and modulated the hair cycle in vivo. This effect is probably related to the paracrine nature of the realization of these growth factors synthesized in the hair papilla. The reason why only paracrine growth factors have a stimulating effect remains not fully clarified.

\section{PLATELET-RICH PLASMA}

The use of autologous PLR as a method indirectly stimulating the work of dermal papilla cells implies large therapeutic 
possibilities. The dermal papilla and connective tissue shell are formed from the same progenitor cells as the fibroblasts in the interfollicular dermis, but their gene expression profile and biological functions are radically different [5-6]. If interfollicular fibroblasts promote the growth and differentiation of the overlying epithelial cells (keratinocytes), the dermal papilla and connective tissue shell play the main role in regulating hair growth. The method is based on the concept of PRP as a natural source of signaling molecules that have a paracrine effect on other cells. The main functions of platelets in restoring damaged tissue are modulation of inflammation through the interaction of innate immune cells, regulation of angiogenesis, and stimulation of cell migration and proliferation.

PRP, isolated from whole blood, is characterized by the presence of growth factors and stimulating mediators. PRP is an autologous platelet preparation in concentrated plasma, with a platelet concentration exceeding the physiological one. Activated $\alpha$-platelet granules produce numerous growth factors, including follistatin, KGF, VEGF, EGF, IGF. These growth factors appear to stimulate cell proliferation and differentiation. It was found that PRP has a beneficial effect on bone transplants performed in maxillofacial, orthopedic surgery and cardiac surgery. Recently, there has been an upsurge of interest in the use of PRP in dermatology, for example, in tissue regeneration, wound healing, fatty tissue transplantation, and for the rejuvenating effects on the skin, suggestions have been made to use PRP as a new treatment for AGA.

\section{THE RESULTS OF THE STUDY OF THE PRP EFFECTIVENESS IN THE TREATMENT OF AGA}

The possible effect of PRP on hair growth has been studied in vitro and in vivo in mice. The actual mechanisms of action on the hair follicle remain controversial: PRP activates the proliferation of dermal papilla cells and prevents apoptosis, which provokes an increase in Akt and Bcl-2 expression levels in vitro. In addition, PRP is involved in the formation of the hair epithelium and the differentiation of stem cells into cells of the hair follicle. Increasing the expression level of FGR-7 prolongs the anagen phase in the hair growth cycle.
In 2006, Ubel et al. [7] reported about a new experience of using PRP in the treatment of male-type AGA. The authors of this study demonstrated that the treatment of follicular units using PRP before transplantation contributed to an increase in hair growth and density. After this study, several studies were conducted to investigate the possibilities of using PRP for the treatment of AGA.

These results became a motive for further research, and since 2006 a number of articles have been published describing the experience of using PRP in the treatment of AGA. Part of the work noted a positive effect from the described technique, part - a negative one.

Researches with a positive result

In 2009, Ggeso et al. [8] published the results of a pilot research on studying the effect of direct injection of PRP into the scalp skin. The study involved 10 people, the evaluation of the results was carried out 4 and 8 months after treatment. An increase in the average diameter of the hair shafts was recorded by $9.7 \%$ at 4 months and by $6.1 \%$ at 8 months in the group of patients receiving PRP. In the control group of patients who did not receive PRP, there was a decrease in the average diameter of the hair shafts by $2.8 \%$ after 4 months and by $3.5 \%$ after 8 months.

In 2010, E. Betsi et al. [9] conducted a pilot study of the clinical effectiveness of PRP injections in the treatment of alopecia. The study involved 42 patients -8 women diagnosed with telogen effluvium and 34 men diagnosed with AGA. Evaluation of the results of the study before and after treatment was carried out using a hair tension test and survey photographs. There was a significant decrease in the number of hair falling out, a significant increase in volume and improvement in hair quality after treatment. Then the researchers noted that more obvious improvements were observed in patients with a history of up to two years; the results were worse for men with 67th stage of baldness based on the HamiltonNorwood scale.

Anitua at al. [10] conducted a blind study of the use of plasma enriched with growth factors in 19 patients with AGA in 2017. Objective methods of assessment using computerized phototrichogram evaluated the result by the following parameters: 1) hair density; 2) diameter; 3 ) the ratio of terminal hair to vellus hair; 4) thinned/normal/dense hair rods among terminal follicles; 5) independent clinical 
assessment of observations (degree of improvement according to macro-photography); 6) epidermal thickness, perivascular inflammatory infiltrate, the amount of epidermal cords, the ratio of terminal hair to miniaturized, the number of collagen, reticular and elastic fibers (according to $3 \mathrm{~mm}$ puncture biopsy); 7) proliferation of epidermal/follicular cells, newly formed blood vessels and the presence of stem cell niches in the bulge zone (according to immunohistochemistry). During the study, the method of single centrifugation was used, the obtained PRP was additionally activated by platelet growth factor to stimulate the release of growth factors and morphogens from the obtained material; centrifuging parameters: frequency - 580 revolutions per minute, time -8 minutes; platelet enrichment ratio $\mathrm{x} 2 \pm 0.3$; blood volume $18 \mathrm{ml}$; PRP volume - 3-4 ml. Patients received 5 intradermal injections in areas of hair loss: 1-4 procedures with an interval of 1 month, 5th procedure -7 months from the start of the study. Evaluation of the obtained results was made after 1 year from the beginning of the experiment, a positive improvement was noted for all 7 evaluation parameters. Subjective assessment data: $85 \%$ of patients noted an improvement in the quality and density of hair; $65 \%$ of respondents noted an increase in hair density.

In 2016, a randomized, placebo-controlled, blind study was conducted by Alves at al. [11] on 25 patients, only 22 of which have fully completed the trials ( 11 men aged from 18 to 65 years with stage II-V of AGA; 11 women aged from 18 to 86 with stage I - III. Subjects were divided into 2 groups: group A, which was administered $3 \mathrm{ml}$ of PRP in the right half of the head and $3 \mathrm{ml}$ of saline (placebo) in the left half; and group $\mathrm{B}$, which received the same solution in both halves of the head. Parameters for evaluating the obtained results (using a photo-trichogram and a survey photo): 1) hair in the anagen phase $(\%) ; 2$ ) hair in the telogen phase $(\%)$; 3) anagen/telogen ratio; 4) density of the hair; 5) density of the terminal hair; 6) counting the amount of hair. The method of single centrifugation was used during the study, the obtained PRP was additionally activated with $0.15 \mathrm{ml}$ of $10 \%$ calcium chloride; centrifuging parameters: centrifugal acceleration $-460 \mathrm{~g}$, time -8 minutes; platelet enrichment ratio $\times 3$; blood volume $18 \mathrm{ml}$; PRP volume $-3 \mathrm{ml}$. Anesthesia was not used. Three injection sessions $\left(0.15 \mathrm{ml} / \mathrm{cm}^{2}\right)$ were carried out, at an interval of 1 month, in four rounded sections of $1 \times 1 \mathrm{~cm}$ of the frontal and occipital part of the head (marked with a medical tattoo). Evaluation of the results was carried out on the 3rd and 6th month, an improvement in the mean values in the anagen/telogen ratio, hair thickness, terminal hair thickness were observed in the areas of PRP administration relative to the initial state, compared with placebo, where only improvement in the average hair thickness was observed. For the first time, the authors were able to detect the relationship between the number of anagenic hair and the age of patients $>40$ years old, the onset of $\mathrm{AGA} \geq 25$ years, the density of hair and the male sex, age $\leq 40$ years, a positive family history of AGA and the duration of the disease $>10$ years. The authors concluded that the use of PRP had a positive effect on the state of AGA and could be considered as adjuvant therapy for the treatment of this disease.

In 2015, data was obtained from a randomized, placebo-controlled, blind study by Gentile et al. [12] on 23 patients, of which only 20 fully completed the tests ( 20 men aged from 19 to 63 years with AGA stage IIa-IV). Onehalf of the affected scalp was injected with PRP injections, the second - with saline. Parameters for assessing the obtained results (1-3 using a computerized photo trichogram and a survey photo): 1) counting the amount of hair and total hair density; 2) density of terminal hair; 3) epidermal thickness and density of hair follicles (according to the data of $3 \mathrm{~mm}$ puncture biopsy); 4) the proliferation of keratinocytes and small blood vessels around the hair follicles (according to immunohistochemistry); 5) AGA relapse. The study used 2 methods: 1) cascade-SelphylEsforax system; 2) the platelet lipotransfer system (PRL platelet-rich lipotransfert system) obtained PPR was further activated by $\mathrm{Ca}^{2}+$; centrifuging parameters were: 1 . centrifugal acceleration $-1100 \mathrm{~g} ; 2$. frequency -1200 revolutions per minute; time: $1,2-8$ minutes; blood volume: $1.18 \mathrm{ml}$; $2.60 \mathrm{ml}$.; PRP volume: 1. $9 \mathrm{ml} ; 2.20 \mathrm{ml}$. During the study, 3 sessions of injections were conducted at an interval of 30 days, without the use of anesthesia, after treatment of the skin with $70 \%$ alcohol, using the method of intradermal injections $(0.1$ $\mathrm{ml} / \mathrm{cm}^{2}$ ). The observation period for patients was 2 years (with the assessment of the condition at the beginning of the experiment, at 
2, 6, 12, 16 and 23 months after the first procedure). A significant improvement in all estimation parameters was noted.

In 2014, a randomized, placebo-controlled, blind study was conducted by Cervelli at al. [13] in 10 patients (10 men aged $20-52$ years with stage IIa-IV AGA). Parameters for evaluating the obtained results (1-4 using a computer phototrichogram and a survey photo): 1) counting the number of hairs; 2) density of hair; 3) density of terminal hair; 4) epidermal thickness and density of hair follicles (according to data of $3 \mathrm{~mm}$ puncture biopsy); 5) the percentage of Ki67 + keratinocytes and the density of the network of blood vessels (according to immunohistochemistry). During the study, the Cascade-Selphyl-Esforax centrifugation system was used, the resulting PRT was additionally activated by $\mathrm{Ca}^{2+}$; centrifuging parameters were: centrifugal acceleration $-1100 \mathrm{~g}$; time: 10 minutes; blood volume: $18 \mathrm{ml}$; PRP volume: $9 \mathrm{ml} .3$ sessions of injections were performed during the study, at an interval of 1 month, without the use of anesthesia, after treatment of the skin with $70 \%$ alcohol, using the method of intradermal injections $\left(0.1 \mathrm{ml} / \mathrm{cm}^{2}\right)$. The period of observation of patients was 1 year (with the assessment of the state at the beginning of the experiment, at 14 weeks, 6 and 12 months after the first procedure). A significant improvement in all estimation parameters was noted.

In 2015, Singhal et al. [14] conducted a placebo-controlled study to compare PRP with approved drug treatment in 20 patients (16 men aged from 25 to 32 years, 4 women aged from 32 to 35). The following parameters were evaluated: 1) hair tension test; 2) hair growth, hair volume, hair quality (method of review photos). The method of double centrifugation was used during the study, the obtained PRP was additionally activated with calcium chloride (in the ratio 9:1); centrifugation parameters were: frequency: 1.1500 revolutions per minute, 2. 2500 revolutions per minute; time: 1.6 minutes, 2.15 minutes; blood volume $20 \mathrm{ml}$; PRP volume - 8-12 $\mathrm{ml}$. 4 sessions of injections were conducted, at an interval of $2-3$ weeks. Injections were carried out by the nappage method, after the skin surface was treated with alcohol and povidoneiodine. The observation period for patients was 3 months (at weekly intervals). A significant improvement in all estimated parameters was noted. For comparison, patients who were offered drug treatment did not notice an improvement in the results of the hair tension test and hair growth in general.

The study by Gupta et al [15] was conducted on 30 patients (30 men aged from 25 to 35 years, with stage III-VII) in 2017. The following parameters were evaluated: 1) hair density (CapilliCare trichoscan); 2) hair diameter (CapilliCare trichoscan); 3) independent clinical evaluation of observations (overview macrophotography). The method of double centrifugation was used during the study. 6 injections were performed at an interval of 15 days, patients were monitored for 6 months. A mezoroller was used before the injections, after which the PRP was injected into the area of the crown (10 $\mathrm{cm}$ from the glabella). A significant improvement in all estimation parameters was noted.

Study Schiavone et al [16] in 2014 were conducted on 64 patients (42 males, mean age 28 years, with AGA stages II-V; 22 females, average age 32 years old, with AGA stage I-II). The following parameters were evaluated: counting the number of hair and hair thickness using a 15-point scale evaluation Jaeschke, clinical changes (macrophotography studied by two independent observers). The study used the method of double centrifugation (GPS III Platelet Separation System, single centrifugation at the first procedure, a two-fold - in 3 months). Plasma protein concentrate was added to the obtained PRP (1st procedure: 6-8 $\mathrm{ml}$ PRP with 3-4 ml). 2 injections were performed at an interval of 3 months; patients were monitored for 6 months. Locally irritating effect achieved after applying local anesthesia (1\% Xylocaine with epinephrine 1:100,000) with skalproller exposure with needles length of $1.0 \mathrm{~mm}$ in order to enhance injected platelet activation, punctures were made at intervals of $1 \mathrm{~cm}$. As a result, the positive effects of the procedures were obtained.

The study by Gkini et al [17] was conducted on 22 patients, of whom only 20 completed the tests completely (18 men, aged from 24 to 72 years, with AGA stage II-5A, 2 women, aged from 58 to 72 years, with AGA stage I) in 2014. The following parameters were evaluated: 1) hair tension test; 2) density and quality of hair (dermatoscopic photomicrography and macrophotography). Centrifugation was carried out using the RegenA-PRPCentri (Regenlab) system using a single centrifugation method. Calcium gluconate was used as an activator 
$(0.1 \mathrm{ml}$ to $0.9 \mathrm{ml}$ PRP in the ratio $1: 9)$. Centrifugation parameters were: centrifugal acceleration $-1500 \mathrm{~g}$, time -5 minutes; platelet enrichment $\times 5.8$; blood volume $16 \mathrm{ml}$; PRP volume $-6 \mathrm{ml}$. There were 3 sessions of procedures (plus 1 procedure to enhance the effect) and at an interval of 21 days (3 procedures at an interval of 21 days plus 1 procedure after 6 months from the beginning), the observation of patients lasted 1 year. Injections $\quad\left(0.05-0.1 \mathrm{ml} / \mathrm{cm}^{2}\right)$ were injected according to the nappage technique into the affected areas to a depth of $1.5-2.5 \mathrm{~mm}$. Positive results were noted for all parameters studied. Subjective assessment data: $85 \%$ of patients noted an improvement in the quality and thickness of hair, $65 \%$ - an increase in hair density.

Also in 2014, another study by Khatu et al. [18] was conducted on 11 patients (11 men, aged from 20 to 40 years, with stages II-IV of AGA). The following parameters were evaluated: 1) hair tension test; 2) counting the amount of hair (Trichoscan); 3) hair loss (clinical examination data, macroscopic photographs). The study used the method of double centrifugation (Manual Double Spin). Calcium gluconate (in the ratio 1:9) was used as an activator. Centrifugation parameters were: frequency: 1.1500 revolutions per minute; 2. 2500 revolutions per minute; time: 1.6 minutes, 2. 15 minutes; blood volume $20 \mathrm{ml}$; PRP volume $-2-3 \mathrm{ml}$. Conducted 4 procedures at a 2-week interval, the observation of patients lasted 12 weeks. After treating the skin with cetavlon, alcohol and povidone-iodine, anesthetic cream was applied to the skin. Injections were administered by the nappage method. As a result, the positive effects of the procedures were seen in all parameters of evaluation.

One of the earliest studies is a placebocontrolled trial by Takikawa et al. [19] in 2011. The experiment involved 26 patients (16 men and 10 women aged from 28 to 59 years). The following parameters were evaluated: 1) average amount of hair (digital and dermatoscopic image); 2) data of cross sections of hair (digital and dermatoscopic image); 3) epidermal thickness, the number of collagen fibers, blood vessels around the hair follicles (according to the $4 \mathrm{~mm}$ puncture biopsy). PRP was used with microparticles of dalteparin and protamine (daltepatin and protamine microparticles - D/P MPs). The study used the method of double centrifugation (Manual Double Spin). Parameters of centrifugation were: frequency: 1.1700 revolutions per minute, 2. 3000 revolutions per minute; time: 1 . 15 minutes, 2. 5 minutes; platelet enrichment $\times 6$; blood volume $15 \mathrm{ml}$; PRP volume $-3 \mathrm{ml}$. 5 procedures were performed at a 2-3 week interval, the observation of patients lasted 12 weeks. Subcutaneous injections $(3 \mathrm{ml})$ were made into selected $1 \times 1 \mathrm{~cm}$ zones located at a certain distance from the tip of the nose and auricle. A positive effect from the administration of PRPs with D/P MPs was noted, and in the administration of simply PRPs zones.

\section{Researches with a negative result}

2 studies were published in 2016, during which there was not observed significant improvement while using of PRT: Puig et al. [20] and the study of Mapar et al. [21].

The first double, blind, randomized, placebo controlled, multicenter study involved 26 female patients, AGA stage II. Patients were divided into two groups: 15 women were included in the group where PRP was used, 11 - in the placebo group. The following parameters were evaluated: 1) counting the amount of hair (photo method); 2) counting hair mass index (Cohen HairCheck system). Centrifugation was performed using the Angel PRP system (Cytomedix), platelet enrichment ratio $\times 2.75-3.4$; blood volume $60 \mathrm{ml}$; PRP volume $-10 \mathrm{ml}$. Patients received a single subcutaneous injection of PRP or placebo with the following evaluation of results after 26 weeks. Anesthesia used included $2 \%$ lidocaine and $0.5 \%$ bupivacaine. No significant changes were recorded at the 26th week, although patients who were administered PRP, noted a slower hair loss, improved hair density, easiness of hair styling, which was not noted by patients from the placebo group.

A second randomized, placebo-controlled, blind study was conducted with the participation of 19 men, of whom only 17 completed the tests completely (17 men aged from 24 to 45 years with stage IV-VI of AGA). The following parameters were evaluated (using a magnifying glass): 1) counting the number of terminal hairs; 2) counting the amount of vellus hair. The method of double centrifugation (Tubex PRP (Moohan Enterprise)) was used in the study. Calcium gluconate $(0.1 \mathrm{ml}$ to $1 \mathrm{ml}$ of PRP) was used as an activator. Centrifugation parameters were: 
frequency: 1. 3000 revolutions per minute, 2 . 3300 revolutions per minute; time: 1.6 minutes, 2. 3 minutes; platelet enrichment ratio $\mathrm{x} 3$; blood volume $9 \mathrm{ml}$; PRP volume $-1.5 \mathrm{ml}$. Square areas on the scalp $2.5 \times 2.5 \mathrm{~cm}$ in size at a distance of at least $3 \mathrm{~cm}$ from each other, marked with tattoos were selected randomly, 2 injection sessions were conducted at intervals of 1 month. Evaluation of the results was carried out on the 1, 3 and 6 months after the first procedure, no significant changes were observed regarding the initial parameters.

\section{CONCLUSIONS}

Positive results were obtained during the 12 clinical studies among the conducted ones, no positive dynamics were observed in the end of other 2 studies. It can be noted that different methods and parameters of centrifugation were used to perform these experiments: PRP used differ or PRP activators were not used at all, variations were observed in methods for evaluating the obtained results, the multiplicity of procedures and intervals between them, the procedure technique (using a mezoroller, anesthetics, injections, etc.). Studies with a negative result were characterized by the smallest number of procedures performed ( 1 or 2 procedures), and methods for evaluating the results cannot be called sufficiently reliable (a magnifying glass).

It is obvious that the use of PRP has a positive effect on the state of AGA and can be used with approved methods of this disease treatment. However, the published results of only a small number of clinical trials on the effectiveness of PRP for hair growth cannot be considered objective. In addition, there is no published agreed protocol for the standard use of PRP, and the use of growth factors and stimulants in the expression of their genes still requires comparative evaluation with preparations approved for the treatment of hair. Thus, the method of PRP using can be considered as a method of treating AGA, however, it is necessary to continue research for further study and standardization of this technique.

\section{REFERENCES}

1. Trihologija. Vtoroe izdanie, dopolnennoe i pererabotannoe / A. Zlotogorskij, D. Shapiro [i dr.]; pod red. A. Litusa; per. s angl. Ju. Ovcharenko. - K.: Izdatel'stvo, 2016. - 276 p., il.

2. Ovcharenko Ju.S., Kachuk Ju.V. Androgeneticheskaja alopecija. // Les Nouvelles Esthetiques Ukraina. 2015. - No. 3 (91). - P. 70-78.

3. Botchkarev V. A., Kishimoto J. Molecular control of epithelial-mesenchymal interactions during hair follicle cycling // Journal of Investigative Dermatology Symposium Proceedings. - Elsevier, 2003. - T. 8. - No. 1. - P. 46-55.

4. Alexandrescu D. T., Kauffman C. L., Dasanu C. A. The cutaneous epidermal growth factor network: Can it be translated clinically to stimulate hair growth? // Dermatology online journal. - 2009. - T. 15. - No. 3.

5. Commo S., Gaillard O., Bernard B. A. The human hair follicle contains two distinct K19 positive compartments in the outer root sheath: a unifying hypothesis for stem cell reservoir? //Differentiation. 2000. - T. 66. - No. 4-5. - P. 157-164.

6. Cotsarelis G., Sun T. T., Lavker R. M. Label-retaining cells reside in the bulge area of pilosebaceous unit: implications for follicular stem cells, hair cycle, and skin carcinogenesis // Cell. - 1990. - T. 61. - No. 7. P. 1329-1337.

7. Barrera A. The Role of Platelet Plasma Growth Factors in Male Pattern Baldness Surgery. - 2006.

8. Greco J., Brandt R. The effects of autologous platelet rich plasma and various growth factors on nontransplanted miniaturized hair //Hair Transplant Forum Int. - 2009. - T. 19. - P. 49-50.

9. Betsi E. E. et al. Platelet-rich plasma injection is effective and safe for the treatment of alopecia // European Journal of Plastic Surgery. - 2013. - T. 36. - No. 7. - P. 407-412.

10. Anitua E. et al. The effect of plasma rich in growth factors on pattern hair loss: a pilot study //Dermatologic Surgery. - 2017. - T. 43. - No. 5. - P. 658-670.

11. ALvES R., Grimalt R. Randomized placebo-controlled, double-blind, half-head study to assess the efficacy of platelet-rich plasma on the treatment of androgenetic alopecia //Dermatologic Surgery. -2016. - T. 42. - No. 4. - P. 491-497.

12. Gentile P. et al. The effect of platelet-rich plasma in hair regrowth: a randomized placebo-controlled trial // Stem cells translational medicine. - 2015. - T. 4. - No. 11. - P. 1317-1323.

13. Cervelli V. et al. The effect of autologous activated platelet rich plasma (AA-PRP) injection on pattern hair loss: clinical and histomorphometric evaluation // BioMed research international. - 2014. - T. 2014. 
14. Singhal P. et al. Efficacy of platelet-rich plasma in treatment of androgenic alopecia // Asian journal of transfusion science. - 2015. - T. 9. - No. 2. - P. 159.

15. Gupta S. et al. A study of the efficacy of platelet-rich plasma in the treatment of androgenetic alopecia in males // Indian Journal of Dermatology, Venereology, and Leprology. - 2017. - T. 83. - No. 3. - P. 412.

16. Schiavone G. et al. Platelet-rich plasma for androgenetic alopecia: a pilot study // Dermatologic Surgery. 2014. - T. 40. - No. 9. - P. 1010-1019.

17. Gkini M. A. et al. Study of platelet-rich plasma injections in the treatment of androgenetic alopecia through an one-year period // Journal of cutaneous and aesthetic surgery. - 2014. - T. 7. - No. 4. - P. 213.

18. Khatu S. S. et al. Platelet-rich plasma in androgenic alopecia: myth or an effective tool // Journal of cutaneous and aesthetic surgery. - 2014. - T. 7. - No. 2. - P. 107.

19. Takikawa M. et al. Enhanced effect of platelet-rich plasma containing a new carrier on hair growth // Dermatologic Surgery. - 2011. - T. 37. - No. 12. - P. 1721-1729.

20. Puig C. J., Reese R., Peters M. Double-blind, placebo-controlled pilot study on the use of platelet-rich plasma in women with female androgenetic alopecia // Dermatologic Surgery. - 2016. - T. 42. - No. 11. P. 1243-1247.

21. Mapar M. A., Shahriari S., Haghighizadeh M. H. Efficacy of platelet-rich plasma in the treatment of androgenetic (male-patterned) alopecia: A pilot randomized controlled trial // Journal of Cosmetic and Laser Therapy. - 2016. - T. 18. - No. 8. - P. 452-455. 